\title{
New records of ferns in the flora of Myanmar found in Natma Taung National Park in the Chin State
}

\author{
Thet Yu Nwe, Myung-Ok Moon ${ }^{1}$, In Chun Hwang ${ }^{2}$, Seung-Hoon Lee ${ }^{3}$ and Byung-Yun Sun ${ }^{4 *}$ \\ Department of Botany, Yangon University, Yangon 11041, Myanmar \\ ${ }^{1}$ Research Institute of Basic Sciences, Jeju National University, Jeju 63243, Korea \\ ${ }^{2}$ Korea Environmental Research Inc., Uiwang 16006, Korea \\ ${ }^{3}$ Endangered Species Restoration Institute, National Park Service, Hampyeong 57167, Korea \\ ${ }^{4}$ Department of Life Sciences, Chonbuk National University, Jeonju 54896, Korea \\ (Received 10 June 2016; Revised 30 August 2016; Accepted 30 August 2016)
}

\section{미얀마 친주 나트마타웅 국립공원내 미얀마 미기록 양치류}

\author{
Thet $\mathrm{Yu} \mathrm{Nwe} \cdot$ 문명옥 $^{1} \cdot$ 황인천 $^{2} \cdot$ 이승훈 $^{3} \cdot$ 선병윤 $^{4 *}$ \\ 미얀마 양곤대학교 식물학과, ${ }^{1}$ 제주대학교 기초과학연구소, ${ }^{2}$ 한국환경기술개발, \\ ${ }^{3}$ 국립공원 종복원기술원, ${ }^{4}$ 전북대학교 생명과학과
}

\begin{abstract}
Field work conducted in Natma Taung National Park, Chin State, Myanmar, in 2015 to make a checklist of lycophytes and ferns resulted in the discovery of four fern species not previously recorded in the flora of Myanmar. All occur in other countries in southeastern Asia, and in other tropical areas. The species are as follows: Adiantum monochlamys (Adiantaceae), Ctenitis decurrentipinnata (Dryopteridaceae), Pteris tripartita, and Paragymnopteris vestita (Pteridaceae). These findings will enable us to update the checklist of ferns of Myanmar.
\end{abstract}

Keywords: Natma Taung National Park, Myanmar, new records of lycophytes and ferns

적 요: 미얀마 친주에 위치하는 나트마타웅 국립공원에 분포하는 석송류와 양치류의 식물상 목록을 완성하 기 위하여 2015년도에 채집을 수행하였으며, 그 결과 4종의 미얀마 미기록 양치류를 발견하였다. 이들은 이웃하 는 동남아국가를 비롯한 열대지역에도 동시에 분포하고 있는 것으로 나타났으며 그 목록은 다음과 같다. Adiantum monochlamys (Adiantaceae), Ctenitis decurrentipinnata (Dryopteridaceae), Pteris tripartita 및 Paragymnopteris vestita (Pteridaceae). 이러한 결과는 앞으로 미얀마 양치류의 목록을 새롭게 작성하는 데 이 용될 것이다.

주요어: 나트마타웅 국립공원, 미얀마, 미기록 양치류

With an area of $678,500 \mathrm{~km}^{2}$, Myanmar is one of the largest countries in Southeast Asia. It is located between $9^{\circ} \mathrm{N}$ and $29^{\circ} \mathrm{N}$ and $92^{\circ} \mathrm{E}$ and $102^{\circ} \mathrm{E}$ and is bordered to the northwest by Bangladesh and India, the north and northeast by Tibet and the Yunnan region of China, and the southeast by Laos and
Thailand. Myanmar has a 1,930 km coastline along the Bay of Bengal and Andaman Sea to the southwest and south.

The flora of Myanmar was extensively documented by British botanists and plant hunters in the early nineteenth century. Dickason (1946) reported 460 species of lycophytes

\footnotetext{
*Author for correspondence: sunby@jbnu.ac.kr
}

Open Access http://e-kjpt.org, (C) 2016 the Korean Society of Plant Taxonomists. This is an open-access article distributed under the terms of the Creative Commons Attribution Non-Commercial License (http://creativecommons.org/licenses/by-nc/4.0) which permits unrestricted non-commercial use, distribution, and reproduction in any medium, provided the original work is properly cited. 
and ferns belonging to 104 genera, and listed 140 species as first records for Myanmar. Before that time, only a few lycophytes and ferns had been collected in Myanmar and enumerated sporadically as part of the exploration of flowering plants. Of the 460 species Dickason (1946) reported, 125 are found on the Malay Peninsula, which is south of $6.5^{\circ} \mathrm{N}$. However, most of his collections had been disappeared because of a lack of adequate maintenance in Myanmar. Moreover, no one until recent times has studied ferns in the country because the literature is insufficient and there are few herbarium specimens; most botanists who have studied in Myanmar have worked solely on flowering plants (Angiosperms). In 20052008, Thet Yu New (2009) studied the fern diversity of KyaikHti-Yoe Wildlife Sanctuary, reporting 68 species belonging to 46 genera and 19 families. These included 12 species new to Myanmar: Araiostegia imbricata Ching, Bolbitis copelandii Ching ex C. Chr. \& Tard., Crypsinus cruciformis (Ching) Tagawa, Crypsinus ebenipes (Hook.) Copel., Doryopteris concolor (Langst. et Fisch) Kuhn, Elaphoglossum malayense Holtt., Davallia trichomanoides B1., Humata vestita B1., Lemmaphyllum carnosum (Hook.) Presel., Microlepia strigosa (Thunb.) Kaulf., Microsorum scolopendrium (Burm. f.) Copel., and Pleocnemia irregularis (C. Presl) Holttum. At about the same time, Fraser-Jenkins (unpubl. data) made a list of 599 taxa of lycophytes and ferns after examining and re-identifying early collections from Myanmar kept in the Royal Botanic Gardens Kew (K), British Museum of Natural History (BM), and University of Michigan Herbarium (MICH), as well as his new collections from Myanmar (unpubl. data). However, our knowledge of the lycophytes and ferns of Thailand and Vietnam, each of which has in excess of ca. 600-700 species (Alston et al., 1939-1951; Tagawa and Iwatsuki, 1979, 1985, 1988, 1989; Boonkerd et al., 2004) led us to predict that many more than the 599 species reported by Fraser-Jenkins (unpubl. data) occur in Myanmar.

Natma Taung National Park in southern Chin State, western Myanmar, was established in 1994 and is located at $21^{\circ} 12^{\prime} \mathrm{N}$, $93^{\circ} 35^{\prime} \mathrm{E}$, close to the border with India and Bangladesh (Fig. 1). It covers around $723 \mathrm{~km}^{2}$ of the Chin Hills and contains the highest peak in southern and central Myanmar: Mt. Natma Taung (Mt. Victoria, elevation 3,051 m). Natma Taung National Park has diverse vegetation that includes a secondary forest consisting mainly of pine and alder near the ridge in Kanpetlet Township situated at an altitude of 1,200 m, a dipterocarp forest dominated by Dipterocarpus and Shorea on the slopes lower than $1,000 \mathrm{~m}$, pine forest on dry ridges and plateaus near the border of the National Park lying at about 1,800 m, oak forests occupying the moist valleys on southern slopes further up, and

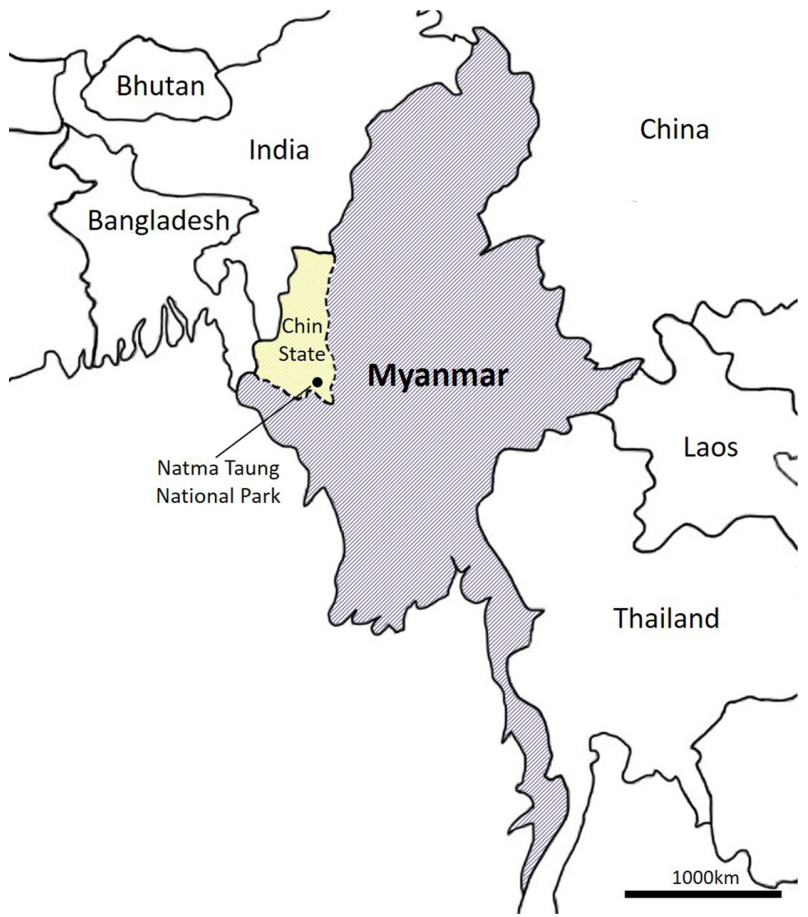

Fig. 1. Location of Natma Taung National Park in Chin State, Myanmar.

a laurel and stone oak forest on the northern slopes up to about 2,500 m. The summit of Natma Taung is open meadow (Fujikawa et al., 2009).

Several scientific explorations involving collaboration between the Forestry Department of Myanmar and Japanese botanists (Fujikawa et al., 2009, 2012, 2013) have examined in the Natma Taung National Park, although their activities have focused solely on flowering plants and no inventories of ferns have been conducted. Therefore, we tried to examine the species composition of ferns inhabited in the Natma Taung National Park. The results provide an update to the checklist of ferns of Myanmar.

\section{Materials and Methods}

Field collections of ferns were conducted from 15 to 30 Dec 2015. Each species was identified and its new occurrence in Myanmar was confirmed using keys and descriptions from the flora records or manuals of adjacent countries, including taxonomic monographs and research papers (Alston et al., 1939-1951; Dickason, 1946; Newman et al., 2007a, 2007b; Thet Yu New, 2009; Lindsay and Middleton, 2013; Wu et al., 2013; Sun et al., 2014; Fraser-Jenkins, unpubl. data). The species are arranged alphabetically by family. The voucher specimens have been deposited in the herbarium of Chonbuk 

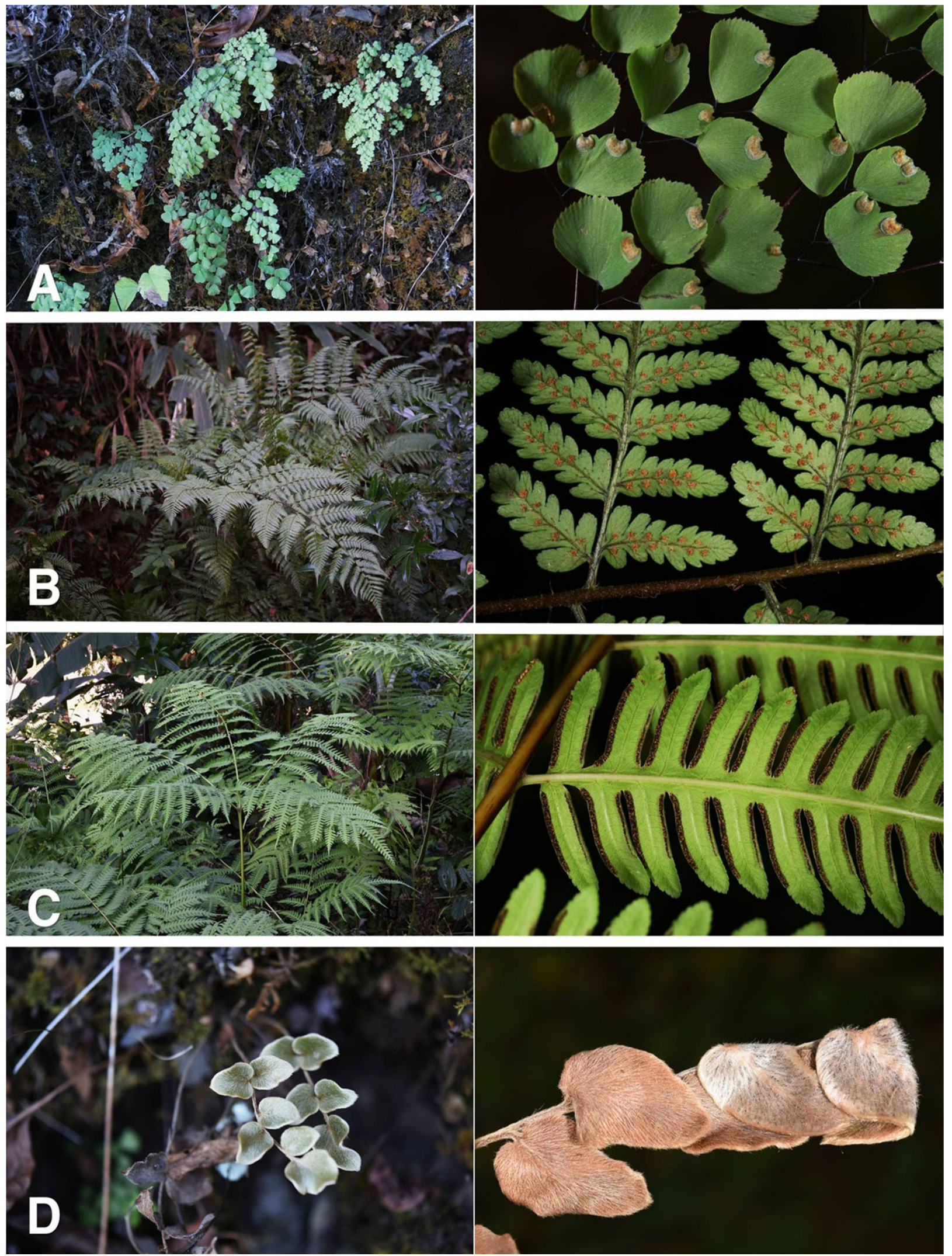

Fig. 2. General habits of ferns new to Myanmar. A. Adiantum monochlamys. B. Ctenitis decurrentipinnata. C. Pteris tripartite. D. Paragymnopteris vestita. 
National University in Korea (JNU) and duplicates are kept in the National Biological Resources Center (KB) of the National Institute of Biological Resources (NIBR) of the Ministry of Environment, Korea.

\section{Results and Discussion}

Four species representing new national records for Myanmar were collected. These species belong to four genera and three families and have been identified in other countries in southeastern Asia. Fig. 2 illustrates the general habits of the species. Description and taxonomic comment of each species was provided as below.

\section{Adiantaceae}

Adiantum monochlamys D.C. Eaton, Proc. Am. Acad. Arts 4: 110, 1858 (Fig. 2A)

Plants evergreen, 25-50 cm tall, 3-10 cm wide. Rhizomes short, densely scaly. Fronds clustered; petiole castaneous, polished, 15-20 cm long, densely scaly at base, glabrous toward apex; blade 2-3-pinnate, ovate to subdeltoid; pinnae 6-8 pairs, spreading obliquely upward; pinnules obliquely ascending, glabrous. Veins several-forked, reaching margins. Sori 1 per segment, covered by reflexed leaf margins.

Specimens examined: MYANMAR. Chin State: Natma Taung National Park, Mt. Victoria, Kamplet-Mindat Road, $21^{\circ}$ 13' 5.6" N 93 57' 55.4" E, elev. 2,503 m, 19 Dec 2015, Sun, Moon, Thetyunwe \& Pak 2491 (JNU, KB).

Distribution: China, Japan, Korea.

Note: This species is usually distributed in open forest at dry rock or cliff. At Natma Taung National Park, this species can be found along the roadside over $2,500 \mathrm{~m}$.

\section{Dryopteridaceae}

Ctenitis decurrentipinnata (Ching) Ching, Bull. Fan Mem. Inst. Biol., Bot. 8: 291-292, 1938 (Fig. 2B)

Plants large, 1-1.5 m tall, 30-50 cm wide. Rhizomes short, erect or ascending, densely scaly at base; scales brownish, narrowly lanceolate. Fronds clustered; petiole $40-70 \mathrm{~cm}$ long, stramineous, scaly, scales reddish brown, subulate, $6-8 \mathrm{~mm}$ long; blade herbaceous, 3-pinnate or 4-pinnate-pinnatifid, triangular-lanceolate, broadest at base, multicelluar hairy adaxially, glandular hairy abaxially; pinnae 12-18 pairs, basal ones largest; basal basiscopic pinnules of basal pinnae enlarged. Veins free, distinct, no veinlets or rarely a few veinlets arising from costae. Sori medial or submedial, indusiate, indusia persistent.

Specimens examined: MYANMAR. Chin State: Natma
Taung National Park, Mindat-Matupi Road, $21^{\circ} 35^{\prime} 38.9^{\prime \prime} \mathrm{N}$, 9341' 53.8" E, elev. 2,381 m, 21 Dec 2015, Sun, Moon, Thetyunwe \& Pak 2516 (JNU, KB).

Distribution: China (Hainan), Southeast Asia (Myanmar, Philippine, Vietnam).

Note: This species is distributed in high mountain areas over 2,500 $\mathrm{m}$ in Mt. Victoria in Myanmar.

\section{Pteridaceae}

Pteris tripartita Sw., J. Bot. (Schrader) $1800: 67,1801$ (Fig. 2C)

Plants terrestrial, up to $2 \mathrm{~m}$ tall. Rhizomes short, erect or ascending, densely scaly at apex. Fronds clustered; petiole stramineous to brownish, up to $1.5 \mathrm{~m}$ long and wide, glabrous, grooved adaxially; blade 3-4-pinnate, tripartite, lateral pinnae 3 branched, terminal pinna pinnate, broadly triangular in outline; first branched lateral pinnae $20-40 \times 15 \mathrm{~cm}$; ultimate segments 8-22 pairs, 8-35 × 3-5 mm, apex rounded, costa grooved adaxially, raised abaxially. Veins anastomosing along the costa and costule, other veinlets simple or 1 forked. Sori continuous along margins of ultimate segment.

Specimens examined: MYANMAR. Chin State: Natma Taung National Park, Mindat-Matupi Road, 2134' 50.2" N, 9335' 42.5" E, elev. 2,214 m, 23 Dec 2015, Sun, Moon, Thetyunwe \& Pak 2512 (JNU, KB).

Distribution: Native to Old World tropics including China, introduced and naturalized in central America and South America. Aslo found in Africa, Australia, Madagascar.

Note: This species is similar to $P$. wallichinana in appearance having large and tripartite leaves. However the two species can be easily distinguishable by the color of stipe and rachis. $P$. wallichiana usually shows red or reddish brown color sometimes with bristles, while $P$. tripartite shows light brownish color.

Paragymnopteris vestita (Hook.) K.H. Shing, Indian Fern J. 10: 230, 1993 (Fig. 2D)

Plants epipetric. Rhizomes erect or decumbent, scaly and hairy; scales subulate. Fronds monomorphic, clustered; petiole 10-20 cm long, terete, densely sericeous; blade oblonglanceolate, 1-pinnate, brown when dry, leathery, densely sericeous abaxially, sparsely sericeous adaxially; rachis and costae sericeous; pinnae 9-15 pairs, ovate, short-stalked, rounded at base or occasionally slightly cordate at base, margins entire, apex obtuse. Veins pinnate. Sori linear, hairy or scaly, exindusiate.

Specimens examined: MYANMAR. Chin State: Natma Taung National Park, Mindat-Pakokku Road, 2122' 14.7" N, 
9359' 24.1" E, elev. 1,202 m, 24 Dec 2015, Sun, Moon, Thetyunwe \& Pak 2588 (JNU, KB).

Distribution: Buthan, China, India, Nepal, Taiwan, Thailand.

\section{Acknowledgment}

This work was supported by a grant from the National Institute of Biological Resources (NIBR), funded by the Ministry of Environment (MOE) of the Republic of Korea (NIBR201604201).

\section{Literature Cited}

Alston, A.-H.-G., C. Christensen and M. L. Tardieu-Bolt. 19391951. Cryptogrames Vasculaires. In Flore Générale de L'IndoChine. Gagnepain, F. (ed.), Masson et Cie, Paris. Pp. 1-600.

Boonkerd, T., S. Lindsay, D. J. Middleton and S. Suddee. 2004. Additions to the Pteridophyte Flora of Thailand. Thai Forest Bulletin (Botany), Thailand 32: 6-11.

Dickason, F. G. 1946. The ferns of Burma. Ohio Journal of Science 46: 109-401.

Fujikawa, K., S. Yasuda, M. Matsumoto, N. Tanaka, S. G. Ngai, H. Mang and A. Din. 2009. A Guide to the Economic Plants of Natma Taung National Park, Myanmar. The Kochi Prefectural Makino Botanical Garden, Kochi, 30 pp.

Fujikawa, K., M. Hamaguchi, N. Yamamoto, H. Ikeda, P. Srisanga and T. M. Soe. 2012. Botanical expedition to Natma Taung (Mt. Victoria) National Park, Chin State, west-central Myanmar in 2012. Newsletter of Himalayan Botany 46: 1-12.

Fujikawa, K., P. Srisanga, C. Maknoi and T. M. Soe. 2013. Botanical expedition to Natma Taung (Mt. Victoria) National Park, Chin State, Myanmar in August to September 2013. Newsletter of Himalayan Botany 48: 1-13.

Lindsay, S. and D. J. Middleton. 2013. Ferns of Thailand, Laos and Cambodia. Retrieved Aug. 1, 2016, from http://rbg- web2.rbge.org.uk/thaiferns/.

Newman, M., P. Thomas, S. Lanorsavanh, S. Ketphanh, B. Svengsuksa and V. Lamxay. 2007a. New records of angiosperms and Pteridophytes in the Flora of Laos. Edinburgh Journal of Botany 64: 225-251.

Newman, M., S. Ketphanh, B. Svengsuksa, P. Thomas, K. Sengdala, V. Lamxay and K. Armstrong. 2007b. A Checklist of the Vascular Plants of Lao PDR. Royal Botanic Garden Edinburgh, Edinburgh, Pp. 1-33.

Sun, B.-Y., I.-C. Hwang, M.-O. Moon and K. Nang. 2014. Biodiversity of Cambodia: Lycophytes and Ferns. National Institute of Biological Resources, Ministry of Environment, Incheon, $208 \mathrm{pp}$

Tagawa, M. and K. Iwatsuki. 1979. Pteridophytes. Part 1: Psilotaceae to Dennstaedtiaceae. In Flora of Thailand. Vol. 3. Smitinand, T. and K. Larsen (eds.), Royal Forest Department, Bangkok. Pp. 1-128.

Tagawa, M. and K. Iwatsuki. 1985. Part 2: Lindsaeaceae to Aspleniaceae. In Flora of Thailand. Vol. 3. Smitinand, T. and K. Larsen (eds.), Royal Forest Department, Bangkok. Pp. 129296.

Tagawa, M. and K. Iwatsuki. 1988. Part 3: Blechnaceae to Athyriaceae. In Flora of Thailand. Vol. 3. Smitinand, T. and K. Larsen (eds.), Royal Forest Department, Bangkok. Pp. 297480.

Tagawa, M. and K. Iwatsuki. 1989. Part 4: Dipteridaceae to Azollaceae. In Flora of Thailand. Vol. 3. Smitinand, T. and K. Larsen (eds.), Royal Forest Department, Bangkok. Pp. 481639.

Thet Yu New. 2009. Diversity of ferns and its identification in Kyaik-hti-yoe Wildlife Sanctuary. $\mathrm{PhD}$ dissertation, Yangon University, Yangon, Myanmar, 146 pp.

Wu, Z. Y., P. H. Raven and D. Y. Hong. 2013. Flora of China. Vol. 2-3 Lycopodiaceae through Polypodiaceae. Science Press, Beijing, 959 pp. 